\title{
Tarihi ve Kültürel Yapıların Korunması ve İncelenmesi; Sandıklı Ulu Cami Örneği
}

\author{
Pinar USTA* \\ ORCID 1: 0000-0001-9809-3855 \\ Isparta Uygulamalı Bilimler Üniversitesi, Teknoloji Fakültesi, Inşaat Mühendisliği Bölümü, Isparta \\ *e-mail: pinarusta@isparta.edu.tr \\ Öz \\ Afyon Sandıkı Ulu Cami; Sandıkı Cuma mahallesinde çarşı içinde Yukarııınar' da yer almaktadır. Sandıklı'nın en \\ büyük camisi olarak bilinen yapı 14. Yüzyılda ahşap direkli ve toprak damlı olarak inşa edilmiştir. 16. Yüzyılda ise \\ minare ve harim bölümleri yeniden yapılmıştır. Tarihi cami 1932 yılında ise esaslı bir onarımdan geçmiştir. Bu \\ çalışmada Sandıkı Ulu Cami'sinin mimari özellikleri anlatılmış ve camiye ait restorasyon ve restitüsyon bilgileri \\ verilmiştir.
}

Anahtar Kelimeler: Tarihi yapılar, kültürel miras, tarihi cami, restorasyon

\section{Conservation and Investigation of Historical and Cultural Structures; Sandıklı Ulu Mosque Example}

\begin{abstract}
Afyon Sandıklı Ulu Mosque is located in Cuma district, Yukarıpınar. The mosque, which is built in 14th century with wood column and flat roof, is known that the biggest mosque of Sandikl. Minaret and harim sections were rebuilt in 16th century. The historical mosque has undergone a thorough restoration in 1932. In this study, the architectural features of Sandıklı Ulu Mosque were explained and restoration and restitution information about the mosque was given.
\end{abstract}

Keywords: Historical building; cultural heritage, historical mosque, restoration

\section{Giriş}

Anadolu, eski çağlardan itibaren pek çok devlete ve uygarlıklara sahne olmuştur. Bu topraklar üzerinde kurulan yerleşim merkezlerinin ve uygarlık merkezlerinin sayısı oldukça fazladır. Sandıklı da bu uygarlık merkezlerinden birisidir. Sandıklı ilçesinin, yerleşmeye ilk defa ne zaman açıldığı ve ilk yerleşik kavimlerin kimler olduğu konusunda kesin bilgiler mevcut değildir. Illçede ilk yerleşime ait izlerin Hititler dönemine rastladığı yapılan araştırmalarda ortaya çıkartılmıştır (Özav ve Yasak, 2016).

Sandıklı, Ege Bölgesi'nin iç batı bölümünde kendi adıyla anılan ova üzerinde kurulu, günümüzde Afyonkarahisar iline bağlı bir yerleşim birimidir (Küpeli, 2010). Sandıklı ilçesinin ve Afyon şehrine uzaklığı 60 km.'dir. İlçe yönetim sahasının doğusunda Şuhut, güneyinde Dinar ve Kızı̈ören ilçeleri,

Atıf: Usta, P.(2019). Ş Tarihi ve Kültürel Yapıların Korunması ve İncelenmesi; Sandıklı Ulu Cami Örneği. Mimarlık Bilimleri ve Uygulamaları Dergisi (MBUD), 4 (2), 201-209.

DOI: $\underline{10.30785 / \underline{m b u d} .431909}$ 
batısında Çardak (Denizli) ve Hocalar ilçesi ile kuzeyinde Sincanlı ilçesi bulunmaktadır. Sandıklı konumu Şekil 1 de görülmektedir.

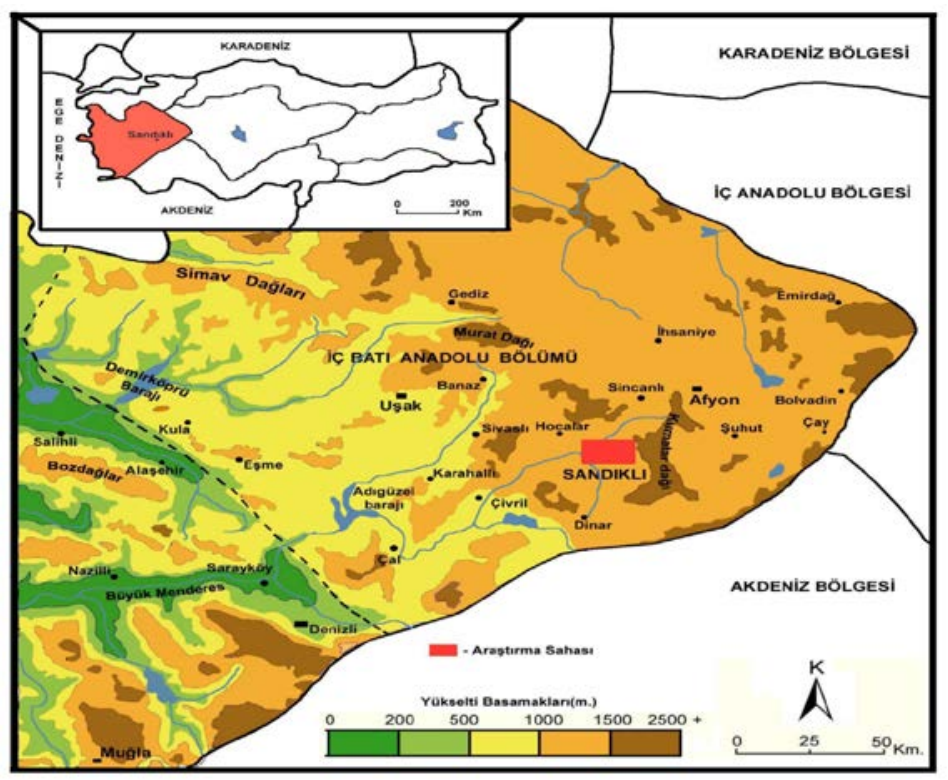

Şekil 1. Sandıklı konumu (Özev ve Yasak, 2013)

Anadolu'nun en eski yerleşim merkezlerinden birisi olan Sandıklı'ın ilk kuruluşunun hangi çağlarda olduğu tespit edilememiştir. Sandıklı'nın bilinen en eski tarihi bakır, tunç ve demir devri dönemlerine kadar gitmektedir (URL-1). Tarihi oldukça eskiye dayanan ve pek çok medeniyetin (Frigyalılar, Lidyalılar, Roma, Bizans, Germiyanoğulları) egemen olduğu sandıklının Türk hakimiyeti ile tanışması 1071 Malazgirt savaşı ile olmuştur. Malazgirt Savaşını kazanan Sultan Alparslan'ın orduları Anadolu'da pek çok şehir, kasaba ve kaleyi ele geçirmişlerdir. Afyon ve civarını ise 1076 yılında Emir Sanduk adında bir Bey fethetmiş ve 1115 yılında da Selçuklu Sultanı 1. Kılıç Aslan Afyon ve kalesini, Germiyanoğulları da Sandıkı yöresini kendi topraklarına dahil etmişlerdir, sonrasında Sandıklının Türk-Bizans hududunda bulunması nedeni ile bir asırdan uzun bir süre savaşlara sahne olmuştur ve 1176 Miryakefalon Savaşından sonra burası tamamen Türkleşmiştir (Topbaş, 1992; URL-1; URL-2; URL-3).

\section{Afyon Sandıklı Ulu Cami Tarihi}

Anadolu'da birçok il ve ilçenin merkezinde ulu câmi bulunmaktadır. İnşa edildikleri şehrin genellikle en büyük câmisi olma özelliğini hâlâ koruyan bu câmilerin büyük çoğunluğu hala ibadete açıktır. Bu camilerin bir kısmı sonraki yıllarda yapılan daha büyük camiler nedeniyle bulundukları yerdeki en büyük cami olma özelliğini kaybetmiştir, bir kısmı ise maruz kaldığı çevresel etkiler nedeniyle (deprem veya yangın) yıkıımıştır. Ulu câmiler, taştan veya taş-tuğla karışımından sağlam bir şekilde inşa edilerek, şehirlerin merkezine yüksek duvarları, minaresi, taç kapısı ve kubbesi ile âdeta hürriyetin bir sembolü olan bayrak gibi dikilmişlerdir. Batıdaki beylik câmilerinde ya tek kubbe vardır veya bir tam kubbenin yanına yarım veyahut küçük kubbeler yerleştirilmiştir. Ulu câmiler, inşa edildiği çağın en iyi aydınlatma usulüyle aydınlatılmaktaydılar. Bu câmiler de mutlaka taş veya tuğladan yapılmış ve çeşitli unsurlarla süslenmiş gösterişli minareler bulunmaktaydı. Kubbeler ise zamanın şartlarına göre keresteden, tuğladan veya kurşun kaplı yapılmaktaydı (Aktüre, 1981; Aydoğdu, 2016; URL-1; URL-4).

Selçuklu döneminde inşa edilen ulu câmiler, Selçuklu Sultanları tarafından Selçuklu hâkimiyetini pekiştirmek için inşa edilmiştir. Anadolu Selçuklularından önce inşa edilmiş olan Güney ve Güneydoğu Anadolu'daki ulu câmiler ise, Memlüklüler ve Emeviler tarafından yaptırılmıştır. Anadolu Beylikleri Dönemi'nde (1290-1380/1402-1450) ise beyler, kendi yönetimlerinde bağımsız bir beylik veya devletçik olduklarını dosta düşmana göstermek için Anadolu'nun birçok yerine ulu câmiler yaptırmışlardır. Böylece idareleri altındaki halka kendi beyliklerinde yaşamanın emniyet ve huzurunu, yüksek minarelerden günde beş defa okunan ezanla ve câmilerde cemaatle kılınan namazlarla yaşatmayı hedeflemişlerdir. Dolayısıyla bir dönem Anadolu'da câmi-i kebîr veya ulu câmi yapmak 'bir iddia sahibi olmak' mânâsına gelmiştir; ulu câmi yaptıran veya adına ulu câmi yaptırılan şahıs, 'ya 
müstakil bir beydir veya sultan adayıdır.' Bağımsızlığın bir başka sembolü olan kendi adına gümüş veya bakır sikke kestirme ile ulu câmi inşaatları birçok beylikte aynı yıllara denk gelmektedir (URL-2; URL-4).

Sandıklı Cuma mahallesinde çarşı içinde Yukarıpınar mevkiinde bulunan Sandıklı Ulu cami Sandıklı'nın en büyük camisidir (URL-5). 708 (1308/1309) hicri senesinde Alaettin Keykubat'ın oğlu Ömer tarafından mimar Naib' in Kölesi Aydemir'e yaptırılmıştır (Aygen, 1973). Vakıf arşivinden alınan bilgilere göre Ulu caminin 14. yüzyılda ahşap direkli toprak damlı olarak yapılmış 16. yüzyılda ise minare ve harim bölümlerinin yeniden yapılmıştır. Ayrıca Mehmet Saadettin Aygen' in 'Afyon Karahisar Camileri' kitabında minarenin 1526 yılında yapıldığı söylenmektedir. Bunun yanısıra bu eserde yapının 1932 yılında esaslı bir onarımdan geçtiği belirtilmiştir. Ulu caminin Kuzey ve batı cephelerindeki betonarme son cemaat bölümü daha sonradan eklenmiştir (Es yapı, 2013). Sandıklı ulu cami Şekil 2'de görülmektedir.

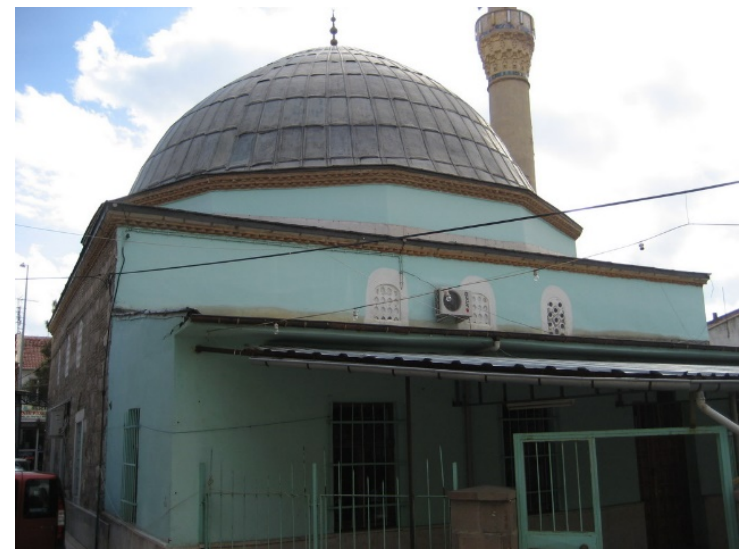

Şekil 2. Sandıklı Ulu cami

\section{Afyon Sandıklı Ulu Caminin Özellikleri}

\subsection{Plan özellikleri}

Sandıklı Ulu Cami, ilk olarak kare planlı tek kubbeli bir mescit olarak inşa edilmiştir. 14. yüzyılda inşa edildiği bilinen ulu cami 16. yüzyılda harim ve minaresi ile birlikte yeniden yapılmıştır. Geç dönemde kuzey ve batı cephesindeki betonarme son cemaat bölümüm eklenmiştir. Şadırvan ve batıdaki çeşme, abdestlikler de yine geç dönemde yapılmıştır.

Tarihi cami 14.54 m. x 14.42 m. ebatlarında kare planlı ve tek kubbelidir. Son cemaat bölümü kuzeyden başlayarak batı yönünde minare kürsü duvarın kadar uzanır. Kuzey cephesinden son cemaat bölümüne iki giriş verilmiştir. Sol taraftaki kapı aksı ile harim giriş kapı aksı aynıdır. İi kapı arasında ikişer pencere vardır. Soldaki kapının sol bölümünde 2, sağdaki kapının sağında da yine 2 pencere bulunmaktadır. Batı tarafında ise 4 adet pencere bulunmaktadır. Yapının Güney duvarında minare giriş kapısı ve mihrap bulunmaktadır.

Doğu duvarında 3 pencere açıklığı vardır. Batı duvarında ise doğu pencere aksları korunmuş ancak; orta akstaki pencere batı duvarına minare yaslandığından açılamamıştır. Batı duvarında iki pencere bulunmamaktadır. Ancak minare kürsüsünün yaslandığı bölüme pencere doğrama figürü tasvir edilmiştir. Güney duvarında giriş kapı aksında mihrap nişi yer almaktadır. Niş yarım daire formundadır. iki yanında başlayan profiller yarım daire formunu tamamlayarak niş üst kotunda birleşmektedirler. Mihrabın iki yanında birer pencere vardır. Güney duvarı üzerinde iki adet vaaz kürsüsü vardır. Bunlardan mihrap ile pencere arasına olan kürsü özgün değildir. Pencerenin solunda kalan kürsü orijinaldir. Minber de güney duvarına yaslanmıştır.

Tarihi caminin toplam da 11 adet tepe penceresi bulunmaktadır. Kuzey, doğu ve güney cephelerinde 3' er adet pencere vardır. Batı cephesinde iki adet bulunur. Aslında 3. pencerede varmış gibi duvara resmedilmiştir (ES yapı, 2013 ve URL-2). 


\subsection{Cephe özellikleri, malzeme ve yapım tekniği}

Batı Cephesi; tarihi caminin minaresi batı duvarına bitişiktir. Minarenin sağında kalan bölümde ise sonradan yapılan üzeri sundurma bir saçak ile kapatılan abdestlikler ve çeşme bulunmaktadır. Minare kürsüsünün sağında kalan harim duvarı almaşık duvar örgüsüne sahiptir.

Güney cephesi; Bu cepheye açılan alt kotta 2 adet pencere üst kotta ise 3 adet pencere bulunmaktadır. Üst kotta bulunan tepe pencereleri yarım daire kemerlidir, Üst ve yan bölümleri ise tuğla söve ile dönülmüştür. Zemin kottaki pencereler düz lentolu ve dikdörtgen formdadır. Söveleri ise taştır. Güney cephesinde bulunan harim duvarı almaşık duvar örgüsüne sahiptir.

Doğu cephesi; almaşık duvar örgülü bu cephede pencereler güney pencereleri ile aynıdır ve yine diğer cephelerde olduğu gibi burada da tepe pencere üzerinden 4 sıra tuğla, 1 sıra kesme taş kullanılmış daha üst bölümde ise kirpi saçağa kadar 6 sıra tuğla yapıımıştır. Cephelerde farklı malzeme kullanımının cepheye zenginlik ve hareket katmak olabileceği düşünülmektedir.

Kuzey cephesi; bu cepheye geç dönemde eklenen son cemaat bölümü sundurma çatıya sahiptir. Son cemaat bölümünün duvarları sıva üzeri boyadır. Sundurma üzeri ise kurşun ile kaplıdır. Son cemaat bölümünün pencere kapıları düz lentolu ve dikdörtgen formdadır. Kuzey cephesinden görülen harim tepe pencereleri yarım daire kemerlidir. Kurşun ile kaplanan kubbe yarım daire şeklinden daha yüksek ve sivri bir forma sahiptir. Minare petek ve gövdesi sıvalıdır. Külah bölümü ise şakülünden kaçmıştır. Sandıklı Cami kuzey Cephesi planı Şekil 3’te görülmektedir.

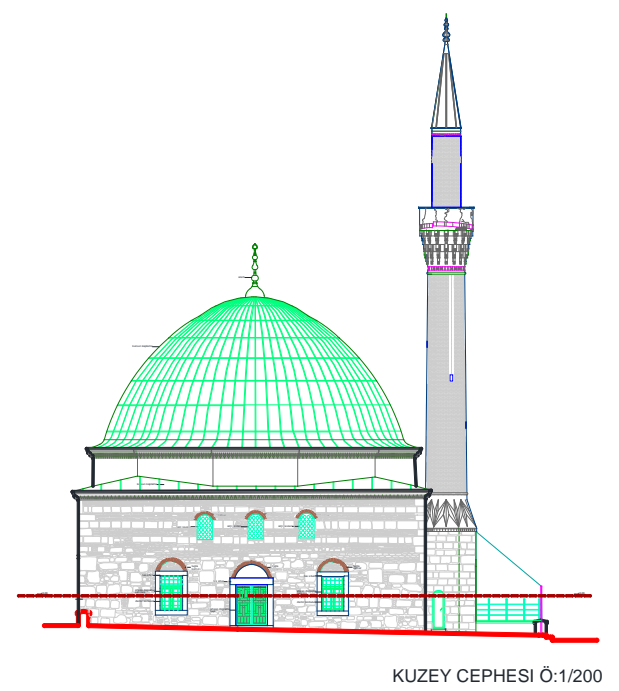

Şekil 3. Sandıklı Cami kuzey cephesi planı

Tarihi yapının kasnağı sıvalı olduğu için malzemesi bilinmemektedir. Duvarları ise , tek ve iki sıra testere dişi dizisi ve profil taş silmeler ile sonlandırımıştır.

\subsubsection{Cami süslemeleri}

Sandıklı ulu cami mimari yapısının yanın da süslemeleri ile de oldukça dikkat çekmektedir. Cami duvarlarında yer alan süslemelerden birçoğu halen durmakla birlikte onarımlardan sonra eski motiflerin bazılarının kaldırıldı̆ı görülmektedir. Duvar resimlerindeki üslup, renk kullanım, motiflerin konumları Anadolu'daki birçok yapı ile benzerlik göstermektedir. İnsan ve hayvan figürlerinin hiç kullanılmadığı camide natürmort, geometrik bezeme, bitkisel bezeme, yazı ağıllıktayken, yapının en dikkat çekici tasvirleri mihrabın hemen üst eksenine yerleştirilen iki adet cami tasvirleridir. Genelde karşılaştığımız mimari tasvirler bitkisel motiflerin oluşturduğu çelenk içinde verilirken, bizim camimizdeki mimariler, bağımsız uçar vaziyette tasvir edilmiştir (URL-2; URL-3).

Sandıkı Ulu Cami süslemeleri döneminin duvar resimleri açısından örnek teşkil etmektedir. Süslemelerinin tarihine ilişkin tarih bildiren bir kitabe yoktur. Bu nedenle sanatçı ve tarihi hakkında herhangi bir bilgi verilememektedir. Bu dönem duvar resimlerinin kronolojik bir gelişim ve bölgesel özellikler göstermemesi, tasvirlerin tarihlendirilememesinin başlıca nedenlerindendir. 
Cami duvar resimleri, Anadolu'daki diğer duvar resimli camilerle benzerlik göstermektedir. Bu nedenle dönemin gezici sanatçıları(ustaları) tarafından yapıldığını düşünülmektedir. Bunun yanısıra Sandıkı Ulu Cami de yer alan duvar resimleri konu ve üslup bakımından Anadolu'daki diğer camilerle benzerlik göstermektedir. Camimizin duvar resimlerinde işlenmiş, natürmortlar, çiçek motifleri, bitkisel ve geometrik bezemeler, vazodan çıkan çiçek motifleri, mimari tasvirlere benzer Anadolu'nun diğer merkezlerinde birçok örnek bulunmaktadır (URL-2; URL-3). Ulu cami süslemelerine ait görseller Şekil 4'te görülmektedir.
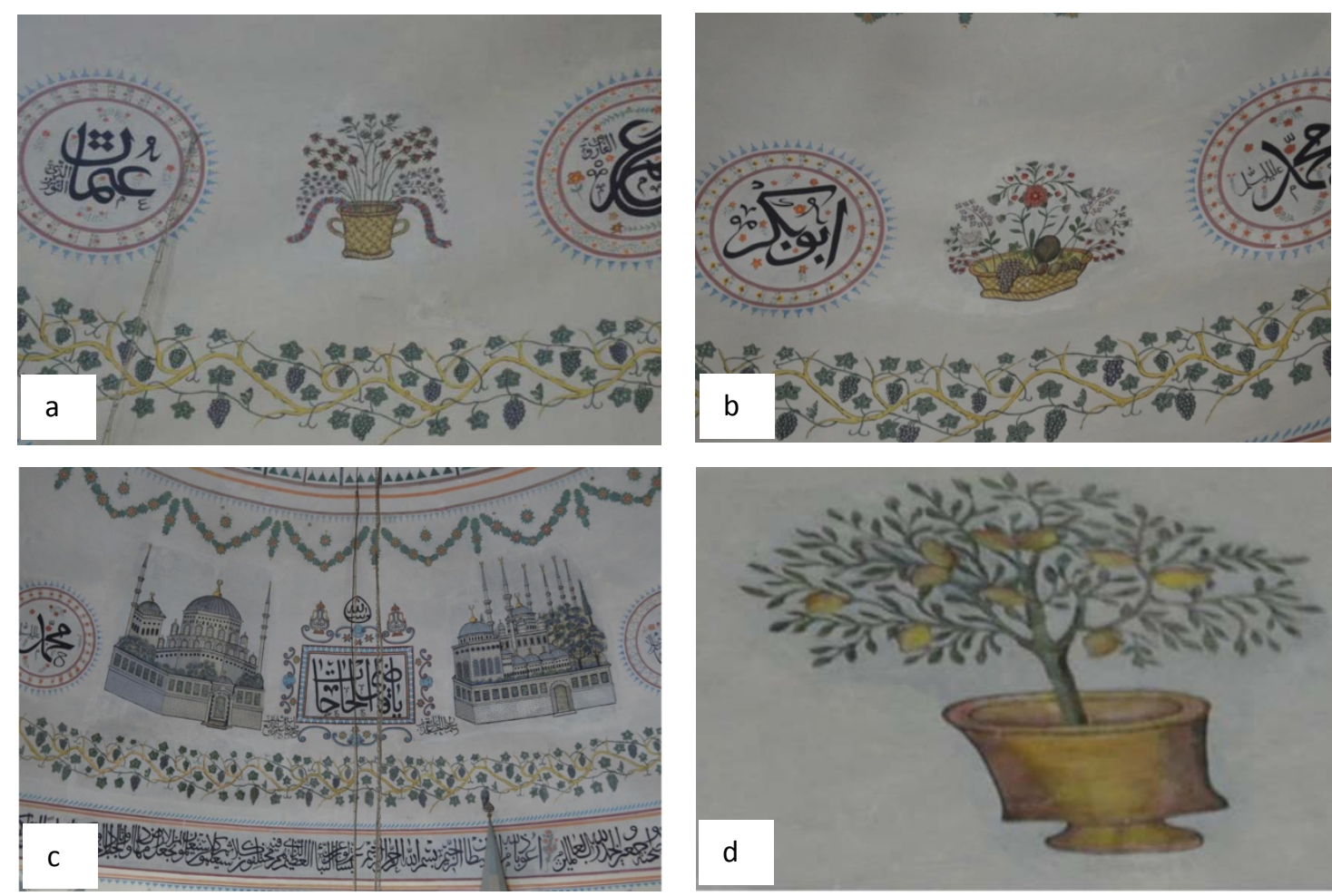

Şekil 4. Ulu cami süslemelerine ait görseller.

(a)Kubbeden Ayrıntı, madalyon ve natürmort tasviri (b)Madalyonlar ve saksıdan çıkan çiçek motifleri, kubbeden ayrıntı, madalyonlar ve saksıdan çıkan çiçek motifleri (c)Kubbede bulunan cami tasvirleri (d)Sandıklı Ulu Cami Limon ağacı tasviri

\subsection{Tarihi Sandıklı Ulu Caminin restitüsyon ve restorasyon raporu}

Yapı ile ilgili yeterli kaynak bulunamadığından vakıflar arşivinden alınan envanter fişleri, kurul kararları ve özellikle kalem işleri ile ilgili hazırlanan ayrıntılı raporlar restitüsyon projesinin hazırlanmasında çok önemli olmuştur. Restorasyon proje ilkesi, yapıların günümüze ulaşan özgün detay ve plan şemasının korunması suretiyle gelecek nesillere aktarılmasıdır. Bu doğrultuda mevcut belgeler ve yapıdaki izler doğrultusunda yapılacak olan uygulamalara karar verilmiş, belge olmayan detaylarda yoruma gidilmemiş mevcuttaki durum korunmuştur.

Ulu caminin restorasyon projesinde şadırvan ve on cemaat bölümleri ile ilgili olarak iki öneri hazırlanmıştır. Illk öneride mevcut betonarme son cemaat bölümü kaldırılmış, şadırvan mevcut durumundaki gibi önerilmiştir.

İkinci öneride ise mevcut betonarme ek yerine günümüzde yapıldığının belli olması için çelik strüktürlü cam kaplama bir son cemaat bölümü önerilmiştir. Cemaat için camii alanı yeterli olmadığından son cemaat yapılmıştır. Mevcut şadırvanda ikinci öneride yine günümüz malzeme ve mimari anlayışına uygun olarak yeniden projelendirilmiştir. Sandıkı Cami yapılması planlan cami ve şadırvan planı Şekil 5 ve 6 'da görülmektedir. 


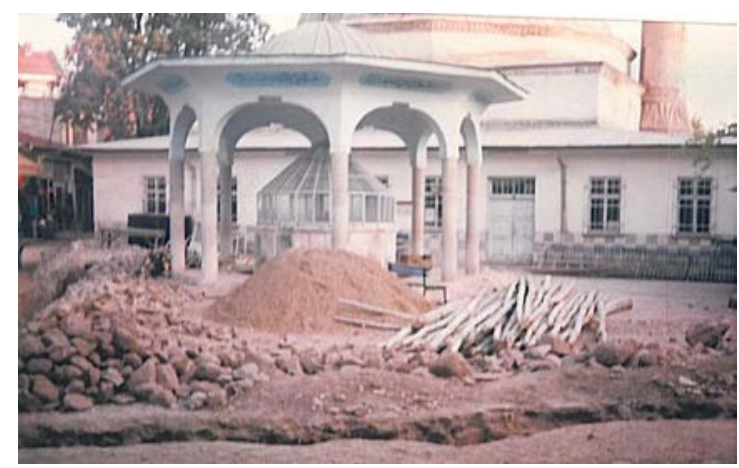

Şekil 5. Vakıflar arşivinden alınan 03.03.2001 tarihinde çekilmiş olan fotoğraf

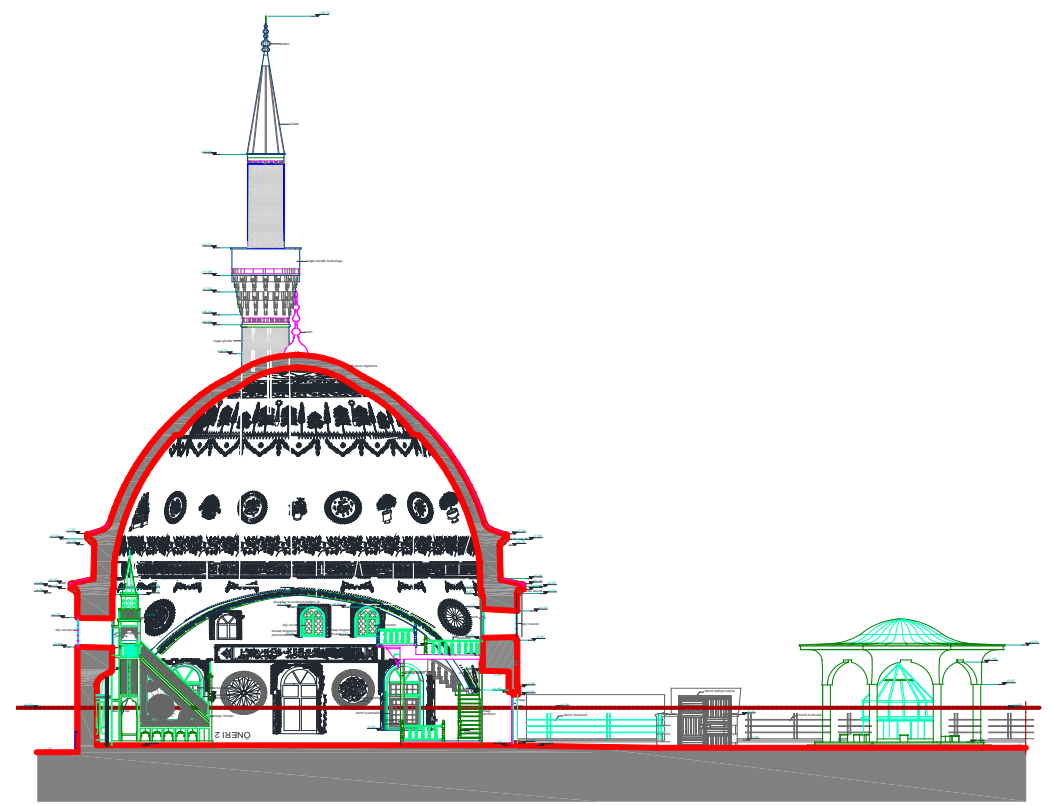

Şekil 6. Sandıklı Cami yapılması planlan cami ve şadırvan planı

Restorasyon projesi restitüsyon projesi doğrultusunda hazırlanmıştır. Camiye eklenen geç dönem eklentileri (betonarme son cemaat yeri, batıda bulunan abdestlikler, çeşme ve üst örtüsü) kaldırılmıştır. Bu şekilde etrafı çevrelenen ve cephe özelliğini kaybeden yapı ortaya çıkarıımıştır.

\section{Bulgular}

Sandıklı Ulu cami için hazırlanan restitüsyon projesi 1526 yılında ki özgün plan şemasına uygun olarak hazırlanmıştır. Camiye ait özgün plan Şekil 7' de gösterilmiştir. Tarihi yapıya ait raporlar incelendiğinde yapıda mevcut olan kelem işi tanzimin orijinal olduğu tespit edilmiştir. Bu nedenle restitüsyon projesinde kalem işleri mevcut durumu ile korunmuştur. Ulu caminin şu anki mevcut durumunda zemin kotunda ve üst kotta bulunan pencerelerde içlikler bulunmaktadır fakat bunlar özgün değildir. Bu durum diğer Dönem camileriyle karşılaştırıldığında çıtalı kanatlı içliklere rastlanmadığı için restitüsyon projesinde doğramalar kaldırıımıştır. Günümüzdeki zemin döşemesi ahşap rabıtadır ve yenidir. Cami örneklerine bakıldığında birçoğunun özgün döşeme kotunun yükseltilerek ahşap yapıldığı görülmektedir. Öyle ki Ulu Caminin minber ilk rıht yüksekliğine dikkat edildiğinde diğer rıhtlardan daha alçak olduğu görülmektedir. Yapıdaki izler doğrultusunda tarihi camiye ait restitüsyon projesinde zemin döşemesi $7 \mathrm{~cm}$ aşağıya alınmıştır. 


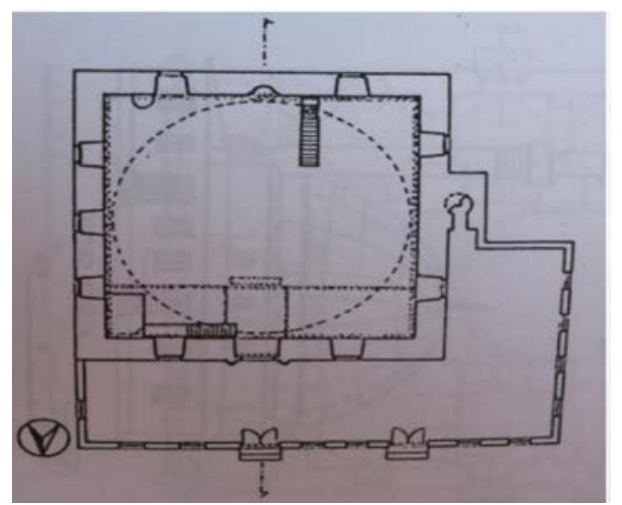

Şekil 7. Sandıklı Ulu Cami Planı (Uysal, 2006)

Restorasyon projesine göre yapının kuzey cephesine raspa yapılmalı özgün doku açığa çıkarılmalıdır. Aynı şekilde mevcut durumda sıvalı olan ve sıvası dökülen yerlerden tuğla olduğu tespit edilen minare gövde ve peteğinde sıvaraspası yapılmalıdır. Minare külah bölümü şakülünden kaymıştır. Bu bölüm sökülerek tekrar yapılmalıdır. Yapının cepheleri almaşık örgülüdür. Yapının Cephelerinde gözle görülür ciddi bir hasar bulunmamaktadır. Atmosferik koşullar nedeni ile kirlenmeler vardır ancak; bu kirlenmeler karbonlaşmamış, tabakalaşmamıştır. Dolayısıyla Atomize su ile temizlenmesi yeterli olacaktır. Ancak uygulama sırasında bu yöntem den sonra kimyasal uygulanıp uygulanmayacağı konunun uzmanlarınca karar verilmelidir. Yapıda bulunan kurşun malzemeler yenilenecektir. Projede yapının avlu zemini traverten olarak önerilmiştir. Sandıklı Ulu cami önerilen Doğu ve Güney cephe planları görünümleri ve önerilen Batı Cephesi Planı Şekil 8 ve 9'da görülmektedir.
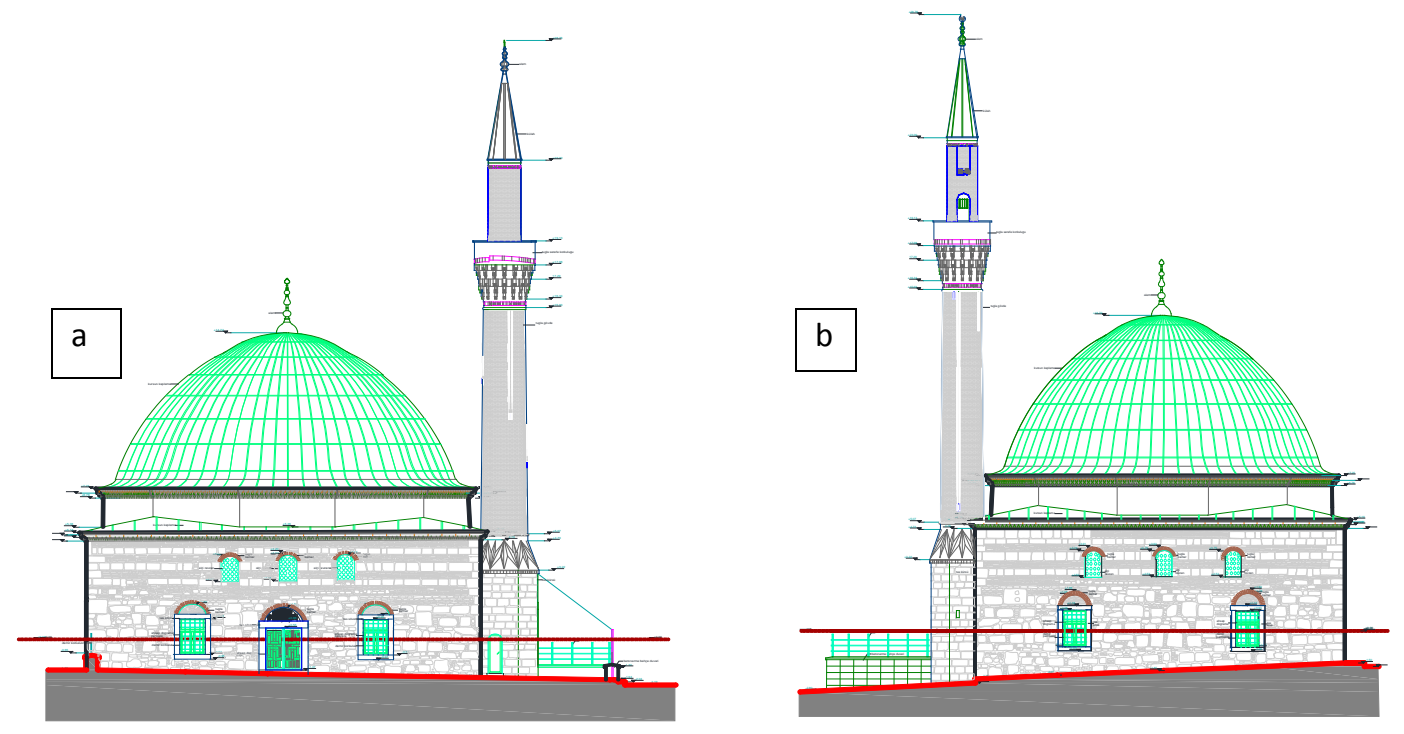

Şekil 8. Sandıklı Ulu cami önerilen cephe planları görünümleri

(a) Doğu cephe görünümü (b) Güney cephe görünümü 


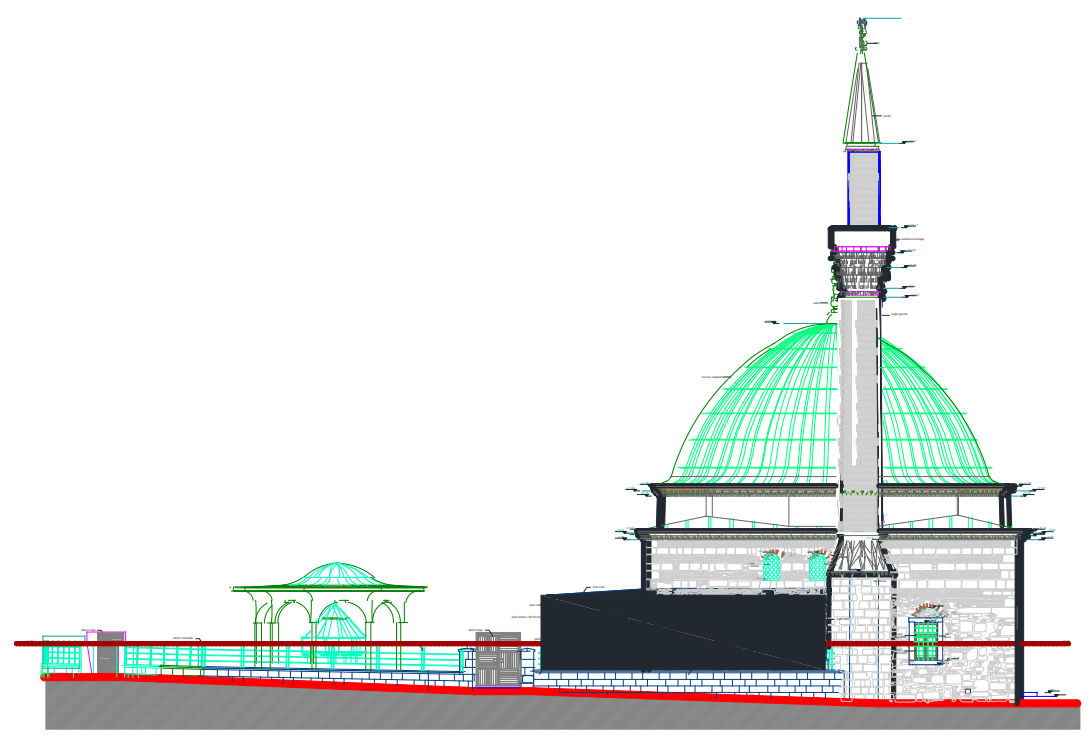

Şekil 9. Önerilen Batı Cephesi Planı

\section{Tartışma ve Sonuç}

Çalışmada ele alınan Sandıklı ulu Cami Germiyanlı devrinde yapılan ve adı bilinen sayılı üç eserden birisidir. Söz konusu caminin 14. yy 'da yapıldığı bilinmektedir. İnşa yılı çok eskiye dayanan bu cami de günümüze kadar birçok onarım ve yenileme çalışmaları olmuştur. Günümüzde tarihinden ziyade süslemeleri de oldukça dikkat çeken camideki bezemeleri yapıya onarımlar sırasında ilave edildiği düşüncesine; daha önceki çalışmalarda 'yapının inşa edildiği dönem özellikleri ile süslemelerin üslup özellikleri arasında bir bağ kurulamayışı' olarak ifade edilen gözlem ve çalışmalar sonucunda varılmıştır. Yine yapılan çalışmalarda süslemelerin genellikle 18-19.yy. Batılılaşma Dönemi ve 20.yy özelliklerini taşıdığı görülmektedir.

Yapıdaki röleve çalışmalarında dönemin kalem işi tanziminin altından günümüzde mevcut olan motifler açığa çıkmış ve çıkan motiflere uygun olarak restorasyon çalışması yapılmıştır. Bu bilgilerden yola çıkarak mevcuttaki kelem işi tanzimin orijinal olduğu tespit edilmiş. Bu nedenle restorasyon projesinde kalem işleri mevcut durumu ile korunmuştur. Hasar gözlenmediğinden kalem işleri için herhangi bir müdahale önerilmemiştir.

Bu çalışmada Sandıklı ulu camisin tarihi ve mimari özellikleri üzerinde durulmuş ve söz konusu yapı için gerçekleştirilen restitüsyon ve restorasyon projelerine yer verilmiştir. Restorasyon projesi restitüsyon doğrultusunda hazırlanmıştır. Yapının projelerinin hazırlanmasında ve binanın okunmasında en büyük sorun tarihi yapının çevresinde bulunan ve sonradan yapılmış eklerdir.

Yapı üzerinde yapılan çalışmalar neticesinde yapıda Yapı genelinde ciddi bir bozulma, Rutubetlenme, kapiler nem olmadığı görülmüştür. 1992 vakıf arşivlerinden alınan kararlarda kubbeden gelen suyun sorun yarattığı fakat kurşunların yenilenerek bu sorunun çözümlendiği tespit edilmiştir. Ulu caminin cephelerinde doğal atmosferik koşullar nedeni ile kirlenmeler meydana gelmiştir.

Yapıya ait önceden elde edilmiş bilgiler kullanılarak mevcut kalem işlerinin orijinal olduğu tespit edilmiş ve bu nedenle hazırlanan projede kalem işleri mevcut durumu ile korunmuş ve herhangi bir hasar olmadığı içinde müdahale önerilmemiştir. Yapının mevcut yer döşemesi ahşaptır ve özgün değildir. Uygulamada kısmı olarak açılma yapılarak özgün doku ve kotu araştırılması yapılmalıdır.

\section{Teşekkür ve Bilgi notu:}

Bu çalışmada Sandıklı Ulu Caminin Restitüsyon ve Restorasyon raporlarını ve projesini bizimle paylaşan ve yardımcı olan ve dolayısıyla bu makalenin hazırlanmasına olanak sağlayan "Es Yapı Şehircilik Mimarlik Restorasyon San. Tic. Ltd. Şti." ne teşekkür ederim. 


\section{Kaynaklar}

Aktüre, S. (1981). 19.yy. Sonunda Anadolu Kenti, Mekansal Yapı, Çözümlemesi, Ankara, s.187-219.

Aydoğdu, G. (2016). Sandıklı Hamamönü Camii'nin Tarihlendirilmesine Dair, Uluslararası Sosyal Araştırmalar Dergisi, Cilt: 9 Sayı: 45, Ağustos 2016 August, Issn: 1307-9581.

Aygen, M. S. (1973). Afyonkarahisar Camileri, Türkeli Yayıncılık, Afyon, 1973.

Es Yapı, (2013). Sandıklı Ulu Cami Restitüsyon ve Restorasyon projeleri. Şehircilik Mimarlık Restorasyon San. Tic. Ltd. Şti. Erişim tarihi: 2013.

Küpeli, Ö., (2010). XVI. Yüzyılda Sandıklı Kasabası, Tarih İncelemeleri Dergisi, Cilt XXV, Sayı:2, 503-526 s.

Özav, Y. ve Yasak, Ü. (2016). Sandıklı ilçesi'nde nüfusun Gelişimi, Sosyal Bilimler Dergisi, 110-128s.

Topbaş, A. (1992). Afyonkarahisar Camileri, Afyon Zafer, 259-260.

Uysal, O. (2006). Germiyanoğulları Beyliğinin Mimari Eserleri, Atatürk Kültür Merkezi Yayınları, Ankara.

URL-1. Erişim Tarihi: 30.04.2019, http://www.afyonkulturturizm.gov.tr/TR-63465/camiler.html, (30.04.2019).

URL-2.

Afyon

Sandıklı

Ulu

Cami, http://www.akmb.gov.tr/userfiles/files/\%C4\%BOLLER\%20VE\%20ULU\%20CAM\%C4\%BOLER\%C4\%B0/AFY ON/SANDIKLI\%20ULU\%20CAM\%C4\%B0\%C4\%B0/SANDIKLI\%20ULU\%20CAM\%C4\%B0\%C4\%B0.pdf (Erişim Tarihi: 30.04.2019).

URL-3. Tiryaki, G., Afyon-Sandikli Ulu Cami, https://www.academia.edu/31682542/AFYON SANDIKLI_ULU_CAM\%C4\%B0.pdf?auto=download. (Erişim Tarihi: 30.04.2019).

URL-4., http://www.sandikli.biz/ulu-cami-cami-i-kebir.html, (Erişim Tarihi: 28.02.2017).

URL-5. http://www.sizinti.com.tr/konular/ayrinti/anadolu-beyliklerinden-yadigar-ulu-camiler.html. (Erişim Tarihi: 28.02.2018)

URL-6. http://sandikli.bel.tr/?sayfa=8\#. (Erişim Tarihi: 28.02.2018). 